Article

\title{
Gaming the System: An Investigation of Small Business Owners' Attitudes to Tax Avoidance, Tax Planning, and Tax Evasion
}

\author{
Diana Onu ${ }^{1}$, Lynne Oats ${ }^{1}{ }^{1}$, Erich Kirchler ${ }^{2}{ }^{-1}$ and Andre Julian Hartmann ${ }^{2, *(\mathbb{D})}$ \\ 1 Business School, University of Exeter, Streatham Court, University of Exeter, Rennes Drive, \\ Exeter EX4 4PU, UK; d.onu@exeter.ac.uk (D.O.); 1.m.oats@exeter.ac.uk (L.O.) \\ 2 Faculty of Psychology, University of Vienna, Universitaetsstrasse 7, 1010 Vienna, Austria; \\ erich.kirchler@univie.ac.at \\ * Correspondence: andre.hartmann@univie.ac.at; Tel.: +43-1-4277-473-33
}

Received: 30 August 2019; Accepted: 29 October 2019; Published: 8 November 2019 updates

\begin{abstract}
To a large extent, the body of research that looks at individuals' compliance with the law focuses on the dichotomy between compliance as rule-following and noncompliance as rule-breaking. However, a fascinating case of noncompliance is that where individuals selectively follow existing rules in order to circumvent the legal principle, this behaviour has been termed 'creative compliance.' In the current study, we investigated the psychological underpinnings of 'creative compliance' by assessing the attitudes of tax avoidance (significant minimisation of tax liability perceived to be legal) and tax evasion (illegal tax minimisation) of 330 owners of small businesses. We found that tax avoidance and tax evasion were perceived as qualitatively distinct by respondents and that they were predicted by different factors. While both tax avoidance and tax evasion were associated with weak personal norms to contribute to the tax system, tax avoidance was associated with a perception that the tax system is unfair, and that tax law has 'loopholes' that can be exploited, while tax evasion was predicted by the perception that evasion is a trivial crime. Overall, we provide insight into the under-investigated behaviour of 'creative compliance' and propose future research directions.
\end{abstract}

Keywords: tax compliance; tax avoidance; tax evasion; tax planning; creative compliance

\section{Introduction}

During the 17th and 18th centuries, the English crown introduced a variety of new taxes to raise revenue and fund military campaigns. One of the most famous, the 'window tax,' was meant to tax subjects based on the size of their properties-size estimated by the number of windows. This measure had rather unintended consequences-many people bricked-up their windows in order to avoid the tax, so much so that bricked up windows is a common architectural feature of the period. From 1766 the tax only included properties with seven or more windows - in the subsequent period, the number of houses in England and Wales with exactly seven windows fell by two thirds [1,2]. Much of academic inquiry into following rules tend to focus on the dichotomy between obeying and breaking the rule, but the example above illustrates the ubiquitous practice of obeying the rule in order to disobey its scope. In this paper, we provide an empirical investigation into this practice of 'creatively complying' with the law and the social and psychological factors that underpin it. We attempt to distinguish the behaviours of (1) playing the system (interpreting the rules in one's favour, i.e., tax avoidance, tax planning) and (2) breaking the rules, in the context of small business owners' compliance with tax regulations (i.e., tax evasion). Specifically, we look at business owners' attitudes involved and the social and psychological factors related to these behaviours. 


\subsection{The Social Nature of Compliance and the Case of Creative Compliance}

The present work broadly deals with the way people behave in relation to laws and regulations. A large literature on the topic regards laws as external influences on individuals in society-faced with these external prescriptions, individuals can choose to either follow or defy them [3]. However, particularly in the last few decades, a movement of scholars of sociology, anthropology, psychology, among others, have emphasized the social nature of the legal process [4]. On the one hand, the drafting of laws is influenced by the lobbying of different groups in society as well as the current social practice. On the other hand, the understanding and application of laws or rules is a subjective process where many social inferences are involved (for instance, one's social class, ethnic group, or their seemingly defiant/apologetic attitude can all play a role). Tax laws and regulations are no exception, as they are subject to be influenced by powerful actors within the field [5], and their application can be influenced by a range of existing social practices [6].

One fascinating illustration of compliance as a social practice is the case of individuals or organisations complying with the 'legal letter' with the very purpose of disregarding the principle it is based on. This behaviour has been labelled 'creative compliance' [7]. For example, [8] cites the case of UK financial sector companies paying large bonuses in shares to salaried employees in order to avoid employment taxes that were only levied on salary payments. She also recounts the way several organisations avoided the value added tax imposed on domestic fuel used for the heating buildings by selling their boilers (which would remain on-site) to external companies who would then sell the fuel to heat the water back to the organisation. The external company would be able to reclaim the value added tax. Organisations would justify this type of arrangement with a "'where does it say I can't do that?' argument" (p. 231), being ready to demonstrate their complete compliance with existing regulations while at the same time avoiding making payments that would have otherwise been due.

\subsection{Creative Compliance with Tax Law: Distinction Between Tax Planning, Tax Avoidance, and Tax Evasion}

The wider tax literature focuses on a binary distinction regarding tax compliance decisions: compliance and non-compliance. However, it is advisable to consider the nuances between the two extremes to gain a deeper understanding of tax decisions (i.e., 'creative compliance': tax planning, tax avoidance). There is no agreed-upon definition of tax avoidance [8-10]. In the following, we review the various approaches, as one of the aims of the study is to empirically investigate the stability of the 'tax avoidance' construct.

Mostly, tax avoidance is defined as the creative design of the tax statement in a legal way with the aim of income reduction and/or an increase of expenditures [11]. It may seem at first glance that the tax arrangements to reduce the tax burden are only relevant to a small number of taxpayers who possess the resources to employ legal professionals who will help them negotiate tax law. However, for instance, it was cited as the widespread practice of avoiding tax in the UK in the early 1990s for some employees to cease being employed and in turn, perform the same work for their former employer through a limited company, thus avoiding employer and income tax [12]. Despite changes in the law, these practices continued and remain controversial. In most cases above, the legislators or tax authorities have stepped in to stop these means of avoiding tax. However, tackling tax avoidance through challenging it in court, introducing new regulation, and pursuing avoiders for debt is not only costly for the regulator, but it can also have a detrimental effect on taxpayers' future cooperation due to feelings of unfairness [13,14].

Even when tax avoidance is only relevant to a smaller number of wealthy individuals or corporations, it's very presence can have a detrimental effect on tax morale [15], as well as wider trust in government and the democratic process [16]. As in reaction, tax authorities try to close those loopholes with new regulations in law, according to [17], this results in a kind of cat-and-mouse legal drafting culture of loophole closing and reopening by creative compliance.

By contrast, tax evasion is generally defined as the illegal act to reduce tax burden [18]. Therefore, it seems easy to demarcate illegal evasion from legal avoidance in theory. In reality, these practices are not as clearly separate. As proposed in the Aggressive Tax Planning: Indicators report by the [19], tax 
planning can have different shadings on the compliance/non-compliance continuum depending on the aggressiveness of the procedure (see Figure 1). Aggressive tax planning is a general term used to describe tax avoidance strategies that comply with the letter but not the spirit of the law. More precisely, the aim of those strategies is to reduce the level of a certain taxable income below the one intended by the legislator [10]. The true rationale of aggressive tax planning is to reduce the effective tax rate at any price by exploiting loopholes, weaknesses or ambiguities in the law (i.e., movement of funds, construction of fictious or shell companies). Since these transactions sail at least close to the wind, it can be assumed that aggressive tax planning contains both elements of tax avoidance and tax evasion [20] and is therefore located between those practices.

\begin{tabular}{ccccc}
$\begin{array}{c}\text { Using tax } \\
\text { provisions in the } \\
\text { spirit of the law. }\end{array}$ & $\begin{array}{c}\text { Rearrange } \\
\text { international flows } \\
\text { to avoid } \\
\text { repatriation taxes. }\end{array}$ & $\begin{array}{c}\text { Reallocate the } \\
\text { tax base to a } \\
\text { lower-tax } \\
\text { country. }\end{array}$ & $\begin{array}{c}\text { Reduce the tax base } \\
\text { via a double } \\
\text { deduction or double } \\
\text { non-taxation. }\end{array}$ & $\begin{array}{c}\text { Illegal measures, } \\
\text { e.g. non } \\
\text { disclosure of } \\
\text { income. }\end{array}$ \\
\hline
\end{tabular}

Aggressiveness of firm behaviour

$\begin{array}{ccc}\text { Tax } & \begin{array}{c}\text { Aggressive tax } \\ \text { planning }\end{array} & \text { Tax evasion } \\ \text { planning } & \end{array}$

Figure 1. Boundaries of aggressive tax planning behaviour retrieved from [19].

Former research on creative compliance puts focus on organisations but has some shortcomings concerning the relevant factors that drive individuals' tax decisions. A possible explanation for this research gap is that many creative compliance strategies require the use of resources and are, therefore, less frequently used by individuals. Further, the role of individual factors is difficult to assess in larger organisational structures where decisions are complex and distributed among many actors. To further investigate the role of psychological factors, hence, we focus on the behaviour of individuals in simple business structures such as sole traders and very small incorporated businesses, and the case of income tax. Although only little past research has looked at the tax avoidance of individuals, a wider literature has been more generally concerned with tax compliance/evasion and the social and psychological factors involved.

\subsection{Psychological Factors: Distinguishing Tax Compliance, Avoidance, and Evasion in Individuals}

Looking at why individuals do or do not comply with tax law, past research has overwhelmingly focused on understanding tax evasion decisions (unusually in relation to income tax), for instance, by looking at the intentional non-declaration of income received. This literature broadly aims to tease out the factors that lead individuals to become involved in the criminal activity of tax evasion, for reviews, see [21-25].

Creative compliance, by contrast, is comparably under-investigated in the tax compliance literature. One barrier is perhaps the fact that, as already mentioned, there is no clear definition of 'tax avoidance' or '(aggressive) tax planning' [8-10,26]. Although tax avoidance is usually defined as a business arrangement set up with the principal purpose of avoiding tax [19], tax arrangements that are considered by some people in some historical periods to be legitimate business practices constitute in other historical periods deeply immoral avoidance of contributing to the public good. [19] argues that such shifts in attitude are cyclical, such that periods of widespread avoidance will follow periods of relatively high commitment to the tax system.

Authors relate tax avoidance to a lack of commitment to the tax system and erosion of tax morale in wider society, e.g., $[19,26]$. Nonetheless, tax arrangements that cause public outcries can be challenged in court by authorities to find that they are ruled to be 'not illegal' [8]. From the perspective of many researchers, these behaviours then become 'compliant' with tax law and do not warrant further investigation. Some authors argue that the use of such emotional terms as 'aggressive tax planning' is 
misleading and unhelpful [27]. These complexities surrounding the definition of tax avoidance are probably one reason for the lack of research into this behaviour. It may seem to some that there really is no such thing as 'tax avoidance,' but what some call 'avoidance' constitutes either 'compliance' or 'evasion' depending on the ruling of courts or interpretation by authorities.

However, [28] looked at the way that evasion and avoidance are perceived by entrepreneurs, tax officers, business students, and lawyers by assessing social representations of these behaviours. They found that people distinguish tax evasion, tax avoidance (use of 'loopholes') and tax flight (i.e., relocating one' business in a different country with a more favourable tax system, which fits under our definition of tax avoidance/creative compliance) as separate types of behaviours, clearly distinguishing the first as illegal and the latter two as legal, but immoral (particularly so for tax flight). In addition, they found that tax avoidance and tax flight were perceived as fairer than tax evasion. The distinction between tax avoidance and evasion is not only apparent in people's lay representations of others' behaviour, but also in their attitudes toward their own tax compliance. [29] has found that some people exhibit an attitude of 'game playing' towards tax authorities. This attitude is distinct from the stance of disengaging with the tax system and operating outside of the system (i.e., evading tax). People displaying an attitude of 'game playing' are, in a way, engaged with the tax system while using existing regulations to defy the system itself. This practice is often seen by those who become involved as clever business innovations and the mark of entrepreneurship, not as committing fraud [19]. Further to this work on game-playing, [29] measured behaviours related to tax avoidance (activities that are not illegal but aim at minimising tax) and tax evasion (illegal withholding of income/overstating expenses) to find that these behaviours are seen as qualitatively distinct by taxpayers, and are both further distinct from compliance. This research demonstrates that although 'tax avoidance' may be at times difficult to define from a legal perspective, tax avoidance is psychologically distinct from both compliance and evasion.

Tax avoidance does not just 'exist' in the minds of individuals as an attitude toward the tax system, it forms a distinct category in public discourse. [15] investigated public reactions to a tax avoidance scandal on social media to show that a large majority of commentators distinguish tax avoidance (arrangements described in terms of 'it may be legal, but it's immoral') from both compliance ('paying one's fair share') and evasion. Of course, capturing what is moral at any given time is difficult. As shown earlier, the definition of what is acceptable practice is socially-situated and will shift in different historical periods or social groups [26]. To attempt to capture what may be seen as tax avoidance in public discourse at one specific point in time, it may be helpful to think of the boundaries of acceptable-unacceptable practice negotiated among different actors in the tax field at a given time [6]. Tax avoidance is likely to be the type of activity that situated itself at the boundary and pushes the boundary [19]. Analyses of lay social representations [28] and public discourse [15] can be helpful for capturing social attitudes in relation to different tax arrangements and current definitions of tax avoidance.

As shown above, tax avoidance is psychologically distinct to both evasion and compliance. [8] construes 'creative compliance' or tax avoidance to be placed in the 'grey area' of the continuum of activities between committed compliance and illegal noncompliance. This also applies to (aggressive) tax planning regarding the report of [19] mentioned above. This continuum approach can be helpful as it aligns with social representations of tax avoidance as being 'less serious' than tax evasion [28]. However, it does not capture the complexity of behaviours involved. In particular, we highlight an essential distinction between behaviours on the continuum. Tax evasion is an act of non-compliance once a tax liability has arisen, it is ex post behaviour. For example, income is received that is subject to income tax but is not declared to the tax authorities. The receipt triggers a tax obligation, but the decision is made not to comply with that obligation by concealing the income. Tax planning, on the other hand, is behaviour that occurs before the crystallisation of tax liability. It is ex ante activity, which allows the taxpayer to choose between alternative ways of arranging their affairs so as to reduce 
future tax liability, and may or may not be successful in achieving this in the long run. We present an illustration in Figure 2.

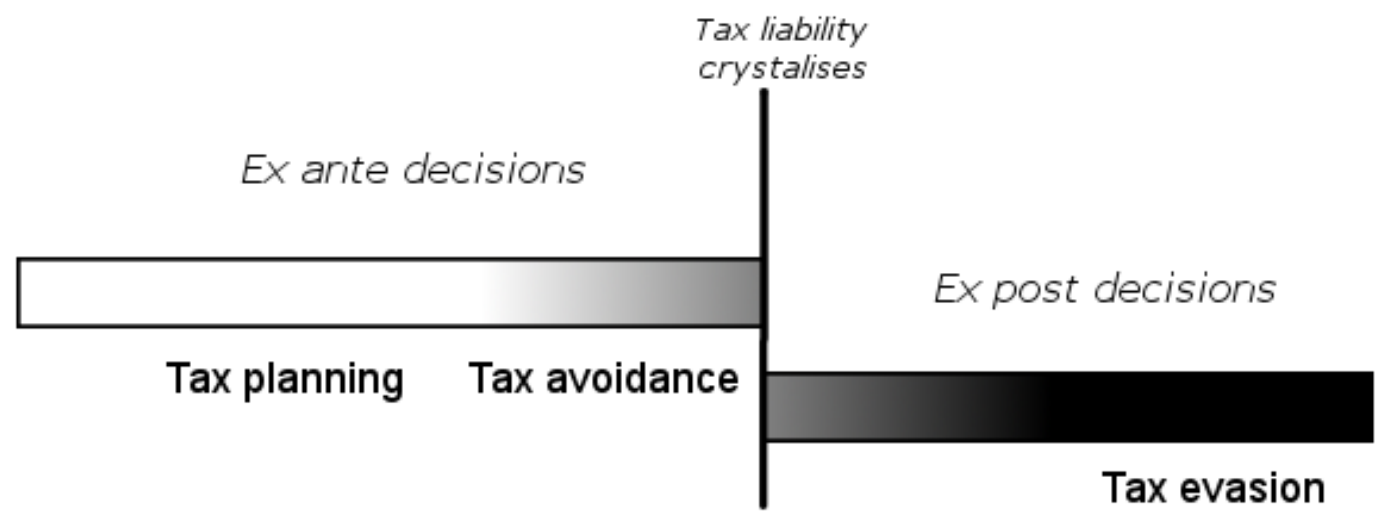

Figure 2. Tax planning, avoidance, and evasion.

\subsection{Factors Involved in Tax Avoidance and Evasion Decisions}

To further explore how tax avoidance differs from evasion, but also how to change these behaviours, we next turn to the factors that may facilitate or impede both avoidance and evasion. Since tax planning may contain elements of both strategies, the factors listed below may equally affect the tax planning behaviour.

Deterrence. One of the most frequently researched factors to influence compliance decisions are penalties imposed on evaders and the perceived likelihood of incurring such penalties. Taxpayers are thought to be deterred from becoming involved in tax evasion by the fines incurred if they are found to evade, as well as other potentially serious implications such as having a criminal record or even imprisonment. In their classic model of tax compliance, [30] propose that people take into account the level of penalty and probability of being found to evade (and sometimes reputational concerns) to calculate the financial benefit of evasion and make a rational profit-driven decision. Although the model was very influential, evidence on the role of audits and penalties is mixed. Reviewing the literature on tax compliance, [31] argue that levels of audits observed in reality are insufficient to explain the high compliance levels observed in society, thus, casting doubt on the validity of the model. Taxpayers may, however, overestimate audit probabilities so that the subjective belief about audit likelihood will influence their decisions [32].

While penalties may constitute a deterrent for tax evaders, these penalties may not apply to avoidance. Avoidance is often presented to taxpayers as an arrangement that can save tax in a 'perfectly legal' way with no financial loss [19]. To explain tax evasion decisions where deterrence seems insufficient, some scholars have turned to the role of social and psychological factors, which we discuss below. These factors become even more important where financial implications seem absent to taxpayers, such as in the case of tax avoidance.

Tax morale. To explain why people comply even when penalties and audits are low, and the rational decision would be to evade, several authors have proposed that taxpayers may comply out of intrinsic motivation to contribute to the public good [33,34], otherwise centred as a personal commitment to tax system [29,35], for instance, shows that such a personal norm to comply with the system explains compliance. Given that both tax avoidance and tax evasion are forms of rejecting cooperation with tax authorities, it is expected that both avoidance and evasion will be related to a sense of low tax morale.

Social norm. Taxpayers may not be committed to the tax system themselves, but they may still be influenced by moral norms in society, for instance, because their reputation as traders would be affected, and they would incur losses in the longer term [36]. Although some studies have shown that both personal and social norm are important in explaining compliance intentions e.g., [35,37] found 
that positive effects of social norms can be explained by the fact that taxpayers possess a personal norm (i.e., high tax morale) consistent with a high compliance norm, and therefore the positive effects are ultimately due to personal norms. When personal norms are low, social moral norms are ineffective if people believe their evasion or avoidance remains private rather than becoming public knowledge [38]. Social norms are only effective if people hold the group as important, i.e., if they identify with the group, [39].

Fairness. Another important factor that has been shown to affect compliance intentions is a sense of fairness - a sense that one receives adequate services for taxes paid and that one is treated fairly e.g., [40-42]. Since tax evasion represents disengagement with the tax system, the role of fairness may be less marked than in the case of avoidance. For instance, research on those becoming involved in mass-marketed avoidance schemes shows that their involvement can constitute a defiant stance towards a tax system that is seen not to serve citizens $[16,19]$.

Knowledge and beliefs about the tax system. Surveying taxpayer attitudes toward tax authorities, [43] shows that some taxpayers defy the tax system by 'playing games' and seeking to take advantage of loopholes in tax law. What underlies this attitude is a belief that the tax system has loopholes to be exploited, and one is confident and knowledgeable enough to exploit these loopholes.

Crime perception. While tax avoiders seek to take advantage of loopholes and avoid contributing to the tax system in a 'legal' way, tax evaders are committing tax fraud by breaking the rules. One factor that may explain people's willingness to evade tax is the perception that tax evasion is not a serious crime [44], given that it can be perceived as a victimless crime [45].

To summarise, both tax avoidance and tax evasion are related to a lack of willingness to cooperate with the tax system, low 'tax morale.' However, avoidance and evasion may also be subject to different factors. Evasion may be related to beliefs that penalties are severe, and audits are likely, and that evasion is not a serious crime. Conversely, avoidance should not be influenced by these factors but be related to a belief that the tax system can be exploited for financial gain and that the imposition of taxes is unfair.

\subsection{The Current Study}

Given that compliance attitudes and the factors influencing these attitudes are most likely to be relevant at an individual level as opposed to larger businesses, in the current study, we look at self-employed individuals and owners of very small businesses. Our focus population is owners of micro-businesses in the UK. Micro-businesses are defined as businesses (incorporated or not incorporated) with under 10 employees and turnover under $£ 1.6$ million ('Commission Recommendation 2003/361/EC', 2003).

We assess tax avoidance and tax evasion using the inventory developed and validated by [46]. The items in the inventory were asking respondents to answer a series of scenario questions about tax avoidance and tax evasion, a method that is advantageous as it may mitigate the desirability bias involved in asking people directly to assess their compliance [47].

We expect to find that tax avoidance and evasion are distinct constructs consistent with [46]. In regard to tax avoidance, the scale employed by [46] focuses on activities that are 'perfectly legal' but allow one to pay less tax than would be due if a different course of action was taken. For instance, they consider the case of a business owner purchasing assets that are not needed for their business in one particular year (but will be needed in the future) in order to decrease their profit, and thus their tax bill, to constitute tax avoidance. However, as discussed earlier, what constitutes 'tax avoidance' shifts in different historical and social contexts. Drawing on analyses of analyses of social media reactions [15] and analyses of online discussions among the self-employed [48], we find that the notion of 'tax avoidance' is rather related to more complex arrangements - for instance, one such case related to the avoidance of income tax and social insurance contributions of an employee by ceasing to be employed in the UK, but instead being contracted by an off-shore company which then hires the services of the employee back to the initial employer. Such 'schemes' are argued as legal by their proponents but can 
be contested by authorities in court or though general anti-avoidance rules [15], for a similar example of 'aggressive tax planning' in Australia see [16]. This type of 'artificial' arrangement to avoid tax is argued in public discourse to be distinct from 'legitimate tax planning' [15]. Given that many scenarios used by [46] to measure tax avoidance capture such 'legitimate tax planning,' we adapted some of the items to fit the perception of 'tax avoidance' (i.e., 'aggressive tax planning') in public discourse at the time of running the survey in the UK. As suggested by [19], we may thus find in the structure of our scale measuring tax avoidance that people differentiate 'legitimate tax planning' and 'aggressive tax planning.'

While avoidance and evasion are expected to be perceived as distinct by respondents, they both constitute forms of non-compliance, so they are expected to be negatively related to people's self-reported compliance. However, given that avoidance and evasion are placed differently on the compliance-noncompliance continuum (see Figure 2), we expect this negative relation to compliance to be stronger for evasion than avoidance.

Finally, as discussed above, we expect several factors to be related to avoidance and evasion. Both evasion and avoidance should be negatively related to people's personal moral norms to contribute to the tax system. We may also find that evasion and avoidance are negatively related to perceived social norms to contribute to the public good. Tax evasion is expected to be related to beliefs that audits are frequent, and penalties are severe and to perceiving evasion as a less serious crime. Tax avoidance, on the other hand, should relate to a belief that the tax system has 'loopholes' that can be exploited and may relate to a sense that the tax system is unfair.

\section{Materials and Methods}

\subsection{Sample}

Within two data collection sessions in February and June 2015 [49]. 330 owners of micro-businesses in the UK participated in the study (76.1\% male). Please see Table S1 in the supplementary material for other demographic characteristics (age, income, education, geography, and business structure).

\subsection{Procedure}

Pilot testing. To increase validity and comprehension, all measures were adjusted following the feedback from a pilot-tested initial sample of 30 small business owners in the UK [50]

Recruitment. A list of business email addresses recommended for use in tax research with small businesses from a UK database was obtained by the researchers [51]. The sample included businesses with under 10 employees, a turnover under $£ 1.6$ million, and included both self-employed individuals (sole traders) and limited companies. Email invitations to take part in the study was sent in two waves, in February and June 2015. The sample represents 1.57\% of all the email addresses that the email was sent to. It should be noted that a significant number of e-mails could not be delivered to the stored e-mail address. The actual response rate was, therefore, considerably higher. In order to maintain anonymity, it was not possible to re-contact participants with reminders in order to increase the response rate. Low response rates are not unusual for anonymous one-shot electronic surveys. However, given the potential response bias, and since the interpretation of absolute levels of variables may not be meaningful for the population of micro-business owners in the UK, we decided only to interpret relations between variables.

Anonymity. In particular, the study was designed to minimise the social desirability and non-responses biases resulting from the legal and moral implications of investigating tax behaviour. To guarantee anonymity, we collected responses using a fully anonymous online survey. Additionally,

1 Some data resulting from this survey was also analysed in Onu et al. [49]. The dynamics of intrinsic and extrinsic motivation in the ethical decision making of small business owners. Under review. 
participants were encouraged to response honest and open as they were assured that they cannot be identified based on their responses. Further, we chose to provide participant payment to all participants in order to minimise self-selection bias.

Questions. Initially, participants were informed about their right to voluntary participation and confidentiality and given a brief overview of the survey topic. The following measures were all captured using 7-point Likert-type scales. After answering all, participants were invited to leave their contact details to receive a $£ 5$ cheque for participation. In addition, they had the opportunity to win shopping vouchers worth up to $£ 100$. In order to guarantee anonymity, the email addresses were collected completely separate from the survey responses.

\subsection{Measures}

Tax planning, avoidance, and evasion. We adapted the scales for measuring tax avoidance and tax evasion developed by [46]. As the scale was initially developed in Austria, we adjusted some of the questions measuring tax evasion to be consistent with UK regulation. As mentioned above, we adjusted two items of the tax avoidance scale, because we thought that the original scale did not capture some of the practices considered in public discourse to constitute 'aggressive tax avoidance' of income tax [15]. Therefore, we replaced the last two items of the original tax avoidance scale with two new items derived from the way 'aggressive' tax avoidance features in public discourse: (1) 'Your accountant recommends a tax scheme. This scheme uses an intermediary offshore company to direct payments from your clients to your business. Your accountant assures you this will generate large tax savings in a legal way. How likely are you to get involved in this scheme?' and (2) 'A friend with a business like yours tells you about their tax advisor. His advisor managed to save him large sums of tax by using loopholes in the tax law. How likely are you to want to use this specialist tax advisor?'.

On subjecting the questions to factor analysis (Principal Components/Direct Oblimin rotation), we found that the items load on three distinct factors that we named tax planning (the practice of finding tax savings that are generally seen as legitimate), tax avoidance (the practice of using regulations in a different way than intended or using structures set up solely for the purpose of saving tax), and tax evasion (practice that illegal such as concealing income or declaring false expenses). Please see Table S2 in the supplementary material for the items of the three scales and their factor loadings. We computed scores for tax planning (mean score of items 1 and 2, $r(330)=.538$ ), tax avoidance (mean score of items 3,4 and $5, \alpha=.716$ ) and tax evasion (mean score of items $5-10, \alpha=.870$ ).

Self-reported compliance. To measure tax compliance participants were asked to what extent they agree (on a 7-point Likert-type scale) with the statements: 'I declare all of my income on my tax return, including all cash earnings' and 'I never over-claim expenses on my tax return' $(r(330)=.549$, $p<.001)$.

Personal moral norms and social moral norms. Personal and social norms were assessed using the single items 'I believe everyone should pay their fair share of tax' for the personal norm and 'Most people believe everyone in society should pay their fair share of tax' for social norm adapted from items measuring norms relating to evasion in [35].

Fairness. We adapted previous measures to access both procedural and distributive justice [41,51]. Two items each were used to assess procedural justice ('HM Revenue and Customs treats me fairly in my dealings with them' and 'HM Revenue and Customs treats me respectfully in my dealings with them') and distributive justice ('The level of tax I pay is generally fair' and 'I receive adequate public services for the taxes I pay'). The results of a principal component analysis (Direct Oblimin rotation) showed that both, procedural and distributive justice load on the same factor. Thus, we computed the four items to assess fairness $(\alpha=.809)$.

Deterrence factors - perceptions of penalties and audits. The perceived seriousness of penalties for one's own business was assessed by the participant's agreement with the following statement: 'If I evaded taxes and got caught, the penalties would be crippling for my business.' The perceived likelihood of audits was assessed with the following statement: 'If I regularly did not declare income 
for tax purposes, I would certainly get caught' adapted from [51]. Our initial intention was to compute the two measures in a 'deterrence' factor. However, the two items were not high enough correlated to suggest they assess a similar construct $(r(330)=.292, p<.001)$, and therefore we decided to assess the role of perceived penalties and audits separately.

Beliefs about the tax system. We assessed beliefs about the tax system using the single item 'The tax system has many loopholes that can help you avoid taxes' adapted from [43].

Tax knowledge. We measured the confidence in one' s own tax knowledge about the agreement to the statement: 'I feel confident and knowledgeable in dealing with taxes.'

Seriousness of evasion. In addition to assessing compliance attitudes, we employed three items to assess individuals' attitudes to tax evasion as a crime. Participants had to rate the following from $1=$ not a crime to $7=$ extremely serious crime: 'Not declaring an extra source of income in your tax return and thereby saving $£ 1000^{\prime}$, 'Claiming a non-existent expense on your tax return and thereby saving $£ 1000$ ' and 'Making cash-in-hand payments to a builder who worked on your home and thereby saving $£ 1000^{\prime}, \alpha=.863$ [45].

Demographic variables. Since demographic variables can explain parts of the variance in tax honesty, gender, age, and education (the latter two by using centile distributions from the UK's Office for National Statistics, 2014) were also used as covariates in the analysis.

Please refer to Table S3 in the supplementary material for descriptive data on the study variables.

\section{Results}

\subsection{Distinguishing Tax Planning, Tax Avoidance, and Tax Evasion}

As described in the previous section, we found three distinct factors in relation to how people positioned themselves in relation to the law. Although we began by using a scale previously designed to measure tax avoidance, we found that respondents distinguish activities of seeking to find tax efficiencies (i.e., which we named 'tax planning') and activities which use the existing regulations in an artificial way with the sole purpose of saving tax (i.e., named 'tax avoidance'). In addition, we also measured tax evasion (i.e., illegal activities of not declaring income or overstating expenses). Consistent with the previous conceptualisation that these three types of behaviours sit on a compliance - noncompliance continuum, we examined the associations between planning, avoidance, and evasion on the one hand, and self-reported compliance on the other. Tax planning had no significant association with tax compliance $(r(330)=.064, p=.243)$, while tax avoidance had a negative association with self-reported compliance $(r(330)=-.298, p<.001)$, as does tax evasion $(r(330)=-.681, p<.001)$. As expected, both avoidance and evasion are negatively associated with compliance, suggesting they are forms of non-compliance. However, the negative association between evasion and compliance is significantly stronger than that of avoidance and compliance, $z=6.695, p<.001$ [47], suggesting that avoidance and evasion are placed on a non-compliance continuum (as illustrated in Figure 2).

\subsection{Predictors of Tax Planning, Tax Avoidance, and Tax Evasion}

To determine the factors related to planning, avoidance, and evasion, we included all the variables measured as predictors (personal norm, social norm, fairness, penalty perception, audit perception, belief about tax system, tax knowledge, and seriousness of evasion) in a linear regression analysis to predict the likelihood of getting involved in the target behaviour. In the first step, we entered the demographic variables used as co-variates. Given that demographic characteristics have been shown to predict tax compliance in past studies, see for example [52] we thought it was important to include them in a first step so we can assess their cumulative effect and the explanatory power of our study variables above and beyond these covariates. Therefore, in the second step, we entered our predictor variables, as described above. Three separate linear regression analyses were conducted, one for tax planning as an outcome, the second for tax avoidance as an outcome, and the third for tax evasion as an outcome. Tables 1-3 present the results of these three analyses. 
The likelihood of becoming involved in tax planning was associated with the belief that the tax system is flexible and allows it to be used for tax efficiencies, as well as confidence in one's knowledge of taxes, as illustrated in Table 1.

Table 1. Regression analyses for tax planning.

\begin{tabular}{|c|c|c|c|c|c|c|}
\hline \multirow[b]{2}{*}{ Predictors } & \multicolumn{3}{|c|}{ Model 1} & \multicolumn{3}{|c|}{ Model 2} \\
\hline & B & SE & $\beta$ & B & SE & $\beta$ \\
\hline Gender & -.146 & .216 & -.038 & -.202 & .212 & -.052 \\
\hline Age & -.259 & .080 & $-.176^{* *}$ & -.236 & .077 & $-.161 * *$ \\
\hline Income & .033 & .057 & .032 & -.006 & .058 & -.006 \\
\hline Education & .080 & .035 & $.123 *$ & .066 & .035 & .101 \\
\hline Audit belief & - & - & - & -.050 & .060 & -.047 \\
\hline Penalty belief & - & - & - & .009 & .059 & .008 \\
\hline Fairness & - & - & - & -.003 & .069 & -.003 \\
\hline Personal moral norm & - & - & - & -.068 & .088 & -.045 \\
\hline Social moral norm & - & - & - & .052 & .056 & .052 \\
\hline Belief about tax system & - & - & - & .195 & .061 & $.170 * *$ \\
\hline Tax knowledge & - & - & - & .232 & .055 & $.235^{* * *}$ \\
\hline \multirow[t]{2}{*}{ Seriousness of evasion } & - & - & - & .053 & .071 & .041 \\
\hline & \multicolumn{3}{|c|}{$\begin{array}{c}R^{2}=.047, \mathrm{~F}(4,329)=3.967 \\
p=.004\end{array}$} & \multicolumn{3}{|c|}{$\begin{array}{c}R^{2}=.147, \mathrm{~F}(12,329)=4.538 \\
p<.001, \text { Д } R^{2}=.100 \\
\mathrm{~F}(8,317)=4.645, p<.001\end{array}$} \\
\hline
\end{tabular}

$$
{ }^{*} p<.05^{* *} p<.01^{* * *} p<.001 \text {. }
$$

Participants' likelihood of becoming involved in tax avoidance was predicted by low personal norms of public good contribution, a sense that the tax system lacks fairness, and the belief that the tax system is flexible and can be exploited for profit, as illustrated in Table 2.

Table 2. Regression analyses for tax avoidance.

\begin{tabular}{|c|c|c|c|c|c|c|}
\hline \multirow[b]{2}{*}{ Predictors } & \multicolumn{3}{|c|}{ Model 1} & \multicolumn{3}{|c|}{ Model 2} \\
\hline & B & SE & $\beta$ & B & SE & $\beta$ \\
\hline Gender & .456 & .173 & $.147^{* *}$ & .338 & .127 & .109 \\
\hline Age & -.122 & .064 & -.103 & -.118 & .063 & -.100 \\
\hline Income & .013 & .046 & .016 & .016 & .047 & .019 \\
\hline Education & -.066 & .028 & .126 & -.059 & .028 & $-.112 *$ \\
\hline Audit belief & - & - & - & .043 & .049 & .051 \\
\hline Penalty belief & - & - & - & .007 & .048 & .009 \\
\hline Fairness & - & - & - & -.129 & .056 & $-.134 *$ \\
\hline Personal moral norm & - & - & - & -.199 & .071 & $-.165 * *$ \\
\hline Social moral norm & - & - & - & -.011 & .045 & -.014 \\
\hline Belief about tax system & - & - & - & .126 & .049 & $.137^{* *}$ \\
\hline Tax knowledge & - & - & - & -.046 & .045 & -.059 \\
\hline \multirow[t]{2}{*}{ Seriousness of evasion } & - & - & - & -.011 & .058 & -.011 \\
\hline & \multicolumn{3}{|c|}{$\begin{array}{c}R^{2}=.049, \mathrm{~F}(4,329)=4.222 \\
p=.002\end{array}$} & \multicolumn{3}{|c|}{$\begin{array}{c}R^{2}=.128, \mathrm{~F}(12,329)=3.887 \\
p<.001, Д R^{2}=.079 \\
\mathrm{~F}(8,317)=3.586, p<.001\end{array}$} \\
\hline
\end{tabular}

${ }^{*} p<.05 ;{ }^{* *} p<.01$. 
Finally, participants who declared they were more likely to be involved in tax evasion perceived tax evasion as a crime that is not serious and had a low public good contribution personal norm, as illustrated in Table 3.

Table 3. Regression analyses for tax evasion.

\begin{tabular}{|c|c|c|c|c|c|c|}
\hline \multirow[b]{2}{*}{ Predictors } & \multicolumn{3}{|c|}{ Model 1} & \multicolumn{3}{|c|}{ Model 2} \\
\hline & B & SE & $\beta$ & B & SE & $\beta$ \\
\hline Gender & .364 & .175 & $.117^{*}$ & .166 & .161 & .053 \\
\hline Age & .138 & .065 & $.116^{*}$ & .153 & .059 & $.129 *$ \\
\hline Income & -.019 & .046 & -.024 & -.025 & .044 & -.030 \\
\hline Education & -.057 & .029 & -.107 & -.047 & .026 & -.089 \\
\hline Audit belief & - & - & - & -.051 & .046 & -.060 \\
\hline Penalty belief & - & - & - & .020 & .045 & .024 \\
\hline Fairness & - & - & - & .039 & .052 & .040 \\
\hline Personal moral norm & - & - & - & -.340 & .067 & $-.281 * * *$ \\
\hline Social moral norm & - & - & - & .034 & .042 & .042 \\
\hline Belief about tax system & - & - & - & .071 & .046 & .077 \\
\hline Tax knowledge & - & - & - & -.099 & .042 & $-.125 *$ \\
\hline \multirow[t]{2}{*}{ Seriousness of evasion } & - & - & - & -.265 & .054 & $-.259 * * *$ \\
\hline & \multicolumn{3}{|c|}{$\begin{array}{c}R^{2}=.038, \mathrm{~F}(4,329)=5.543 \\
p=.014\end{array}$} & \multicolumn{3}{|c|}{$\begin{array}{c}R^{2}=.245, \mathrm{~F}(12,329)=11.961 \\
p<.001, \text { Д } R^{2}=.207 \\
\mathrm{~F}(8,317)=1.857, p<.001\end{array}$} \\
\hline
\end{tabular}

Given that we did not find that audit or penalty beliefs have an impact on tax evasion, as expected, we performed a regression analysis to look at the role of these factors separately. We entered penalty belief and audit belief in the regression analysis as predictors (controlling for demographic variables as above), to find that, in the resulting model $(\mathrm{R} 2=.069, p=.001)$, audit belief was a significant predictor of tax evasion $(\beta=-.145, p=.010)$, but not penalty belief $(\beta=-.072, p=.209)$. However, the significant effect of audit belief disappears with the inclusion of personal norms and seriousness of evasion predictors, as reported above. This result suggests that the effect of audits on evasion may be explained (mediated) by personal norms and seriousness perceptions (as discussed in the next section). We tested this proposition of an indirect effect using the PROCESS algorithm [53] and found that there are significant indirect effects from audit belief to evasion through both personal norms (LLCI $=-.084$, $\mathrm{ULCI}=-.023)$ and perception of evasion as a serious crime (LLCI $=-.077, \mathrm{ULCI}=-.016)$.

\section{Discussion}

Inquiries into the nature of tax compliance behaviour have focused overwhelmingly on the dichotomy between compliance and evasion [46], between 'following the rule' and 'breaking the rule.' Tax compliance research is not unique in this respect, much of the literature on organisational compliance with regulations has construed behaviour as binary - compliance/noncompliance with rules. However, it is not uncommon for people to use rules in order to avoid being compliant [8]. Overall, we know little about the nature of this 'creative compliance' behaviour and its facilitating factors. Our analysis has attempted to disentangle noncompliance (i.e., tax evasion) and creative compliance (i.e., tax avoidance, tax planning) and look at their predictors.

Our study contributes empirical evidence to the field of tax behaviour and in particular, the under-investigated area of tax avoidance $[28,43,46]$. We replicate past results showing that people distinguish evasion and avoidance as separate forms of non-compliance [46], while additionally showing that people distinguish tax avoidance from legitimate tax planning. Furthermore, we provide novel evidence of the factors associated with people's reported likelihood to be involved in evasion 
and avoidance, providing empirical evidence to support the 'creative compliance' model proposed in the legal literature $[7,8]$ and contributing more broadly to the literature on the nature of compliance [3]. We detail these contributions below.

While attempting to capture tax avoidance behaviour we found that people distinguish two different behaviours: tax planning as the legitimate practice of finding tax efficiencies and tax avoidance as the practice of finding 'loopholes' in the law in order to significantly minimise tax contributions. These two behaviours are also distinct from tax evasion. We found that the three behaviours - planning, avoidance, and evasion - are situated on the compliance-noncompliance continuum, as illustrated in Figure 2. While tax planning is unrelated to compliance, suggesting that the likelihood to be involved in tax planning is not related to noncompliance, both avoidance and evasion are situated in the noncompliance area, with evasion further to the noncompliance end of the spectrum (see Figure 2).

Although planning, avoidance, and evasion can all be placed on the compliance-noncompliance spectrum, it is important to stress that they are distinct behaviours with different facilitating factors. Unsurprisingly, both tax planning and tax avoidance are underlined by a belief that the tax law is flexible and can be used to find tax savings. In addition, people likely to be involved in tax planning feel more confident in their knowledge of tax law. Tax evasion, on the other hand, is unrelated to beliefs about the tax system. As expected, both avoidance and evasion are related to a low personal norm to contribute to the public good, or low 'tax morale,' while no such negative relation underlies tax planning. However, avoidance and evasion differ in relation to other predictors. Avoidance is associated with a sense of unfairness (that one is not receiving adequate services for taxes paid and is treated unfairly). Evasion, on the other hand, is associated with the perception that tax evasion is not a serious crime.

These results are consistent with our initial expectations and previous literature that tax avoidance, as well as evasion, are underlined by an attitude of noncompliance - a low moral norm to contribute to the tax system $[8,35,54]$. However, avoidance and evasion are driven by different factors. In effect, they are different routes to contribute less to the tax system. People who believe the tax system allows interpretation in order to minimise tax contributions and who assess the tax system as unfair are more likely to say they would become involved in tax avoidance. These results are consistent with previous conceptualisations of creative compliance as determined by both a negative attitude towards the tax system [8], as well as feelings that the tax system may not serve citizens [16]. By contrast, such factors are unrelated to tax evasion. People who said they are likely to become involved in evasion are those who see evasion as a less serious crime. This result is consistent with previous research that found that tax evasion to be perceived as a trivial offence [55] or a victimless crime, and thus less serious by people likely to become involved in evasion [45].

It may be surprising that tax evasion was not associated with perceptions of deterrence factors such as audits and penalties [30]. On closer inspection, we found that when deterrence factors were considered independently of other variables, there was a significant relationship between the belief that audits are likely and tax evasion. Penalty beliefs did not have a significant effect, perhaps because penalties are public knowledge, but audit rates are private so that subjective beliefs about audits are more likely to have an effect than subjective beliefs about penalties. An alternative explanation may be that penalties would be perceived not as deterrents but as fair compensation for evasion [56]. However, when other predictors are considered, this audit belief effect is mediated by a low compliance personal norm as well as the perception that evasion is not a serious crime. The mediation by personal norm and evasion as serious crime suggests that people may express a belief that they are less likely to get caught to rationalise their involvement in tax evasion, but the primary factors driving their behaviour is to be consistent with their personal standard of behaviour and pre-existing attitudes. Previous research has suggested that people may offer post-hoc rationalisations of evading tax - although they may make rational self-interested decisions, they may then 'make up' a moral reason to justify their actions for an analysis of these processes see [57]. The current result suggests the opposite - that people evade in order to be consistent with personal norms of behaviour and existing attitudes but will 
rationalise their behaviour as 'business savvy.' This result is novel, but consistent with the fact that personal norms are a strong predictor of behaviour in a variety of domains see [38] as are attitudes in certain instances [58]. Although people may be driven by personal norms or attitudes, they may offer a post-hoc rationalisation of their action by saying they made a rational decision given that many people seek to appear to act in a rational profit-driven way which is valued in society as entrepreneurial, norm of self-interest [59]. While this result is interesting, further research is needed to investigate such post-hoc rationalisation of evasion as a rational decision in more detail.

Based on previous research, we also explored the possibility of a negative relationship between social norms to contribute to the public good and avoidance and evasion [16,35]. One possible explanation for the lack of a social norm effect is that moral norms are only effective drivers of behaviour when the behaviour is public, but people may expect their tax affairs to remain private. We also found an unexpected negative association between tax knowledge and tax evasion. One explanation for the effect may be that some of our sample had low knowledge of tax and may have honestly not realised that some scenarios listed constitute tax evasion (for instance, [60], found that there is genuine confusion among hairdressers as to whether tips should be declared as income or not). Furthermore, we found a positive association between tax knowledge and tax planning, on which we could suggest that people with higher text knowledge use their knowledge to plan their tax behaviour a priori instead of evading taxes.

Overall, we provide empirical evidence of the distinction between tax planning, avoidance and evasion, and factors related to the three behaviours. Our results are interesting to scholars looking at tax compliance decisions, where tax avoidance has received relatively little attention $[16,28,46]$. Nonetheless, tax avoidance is a particularly interesting case of noncompliance for scholarly research. The tax compliance literature has largely focused on two types of factors affecting tax compliance: deterrence (i.e., fines) and socio-psychological factors (e.g., attitudes, norms, fairness) for a review see [24]. Those involved in avoidance perceive it as 'perfectly legal' and unlikely to incur any financial risk [46]. Therefore, financial deterrents are perceived to be. However, despite this belief, not all taxpayers become involved in tax avoidance, as many perceive it to be 'immoral' [16]. Thus, the role of social and psychological factors is even more relevant in understanding why people do or do not choose to be involved in tax avoidance than in the case of evasion, so it becomes particularly fertile ground for studying the role of social and psychological factors in tax compliance.

More broadly, we contribute to the literature on the nature of compliance [3] and 'creative compliance' in particular $[7,8]$. We do not only find that people construe avoidance and evasion as distinct forms of noncompliance, but that they further distinguish 'tax planning' as a separate category. 'Creative compliance' (in this case, 'tax avoidance' or 'aggressive tax planning') may be difficult to define from a legal point of view, as one takes the view that 'creative compliance' is rendered compliance or non-compliance by a court verdict e.g., [27]. However, we find that people distinguish 'creative compliance' with tax law (i.e., avoidance) as a distinct behaviour and a form of avoiding to contribute to the tax system. Scholars have also noted that, beyond the nature of the law, attitudes are important to understand people's involvement in 'creative compliance' e.g., [8,26]. Our results confirm this proposition as we find people who report being more likely to be involved in avoidance have a negative attitude towards contributing to the tax system as well as a belief that the law can be taken advantage of.

We provide novel evidence regarding the factors associated with tax avoidance that may be useful to tax authorities. The results suggest that in order to tackle involvement in tax avoidance, tax authorities need to tackle the belief that the system has loopholes that are easy to exploit for profit. At the same time, taxpayers may be less likely to become involved in tax avoidance if they perceive the tax system as providing adequate services for taxes paid and that they are treated fairly by authorities.

Although we provide initial insights into nature and factors driving of tax avoidance, as well as tax planning and tax evasion, it is important to note that further research is necessary to increase certainty in the current results. Our questionnaire data is correlational, we interpreted results in line with 
previous research (i.e., where variables such as audit beliefs or personal norms constitute predictors and evasion/avoidance the outcome), but it is not unconceivable that some relations would be reversed so that respondents' ratings of their personal moral norms are mere post-hoc justifications of behaviour, although for an analysis providing evidence against the rationalisation argument, see [57]. Field or laboratory experiments would further provide evidence in support of the directions of the effects presented here. It is also important to note that we have only measured people's reported intentions to become involved in avoidance or evasion. First, this measure may be subject to social desirability biases as people may be unwilling to report the true extent of their intentions [61], although we mitigate this effect by respondents being anonymous and by employing scenario measures. Second, and maybe more pertinent to predicting behaviour, people may entertain the idea of avoidance or evasion, but many other variables are involved in whether they actually become involved [62], such as having the opportunity to do so, employing an adviser willing to support them, etc. Further research on institutional data related to people having been involved in tax avoidance may be used to corroborate findings relating to attitudes or intentions e.g., [16].

Tax avoidance has important social implications for the erosion of confidence in the tax system [14] and the democratic process [16], and can also constitute lost revenue for the state through non-payment e.g., [63] and through the cost of pursuing avoiders in court and recovering tax debt. Despite its implications and, at times, intense public interest in tax avoidance, the topic has received relatively little attention from scholars. We hope that the present study will be useful in catalysing further research on the psychological nature of tax avoidance in particular, as well as 'gaming the system' in contexts other than tax.

Supplementary Materials: The following are available online at http://www.mdpi.com/2073-4336/10/4/46/s1, Table S1. Sample characteristics; Table S2. Factor analysis results for tax planning, avoidance and evasion items; Table S3. Variables - descriptive statistics and correlation among study variables.

Author Contributions: D.O.: conceptualisation, data collection, formal analyses, and writing - original draft preparation. L.O.: conceptualisation, funding acquisition and writing - original draft preparation. E.K.: Interpretation and writing - review and editing. A.J.H.: Visualisation and writing - review \& editing.

Funding: This work was conducted in the Tax Administration Research Centre at the University of Exeter, jointly funded by the Economic and Social Research Council, HM Revenue \& Customs and HM Treasury (grant no. ES/K005944/1). Open Access Funding by the University of Vienna. The views expressed in this report are the authors' and do not necessarily reflect those of the funders. We are very grateful to our funders for their support.

Conflicts of Interest: The authors declare no conflict of interest.

\section{References}

1. Window Tax. (n.d.). Retrieved 27 April 2016. Available online: http://www.parliament.uk/about/livingheritage/transformingsociety/towncountry/towns/tyne-and-wear-case-study/about-the-group/housing/ window-tax/ (accessed on 31 October 2019).

2. Oates, W.E.; Schwab, R.M. The Window Tax: A Case Study in Excess Burden. J. Econ. Perspect. 2015, 29, 163-180. [CrossRef]

3. Edelman, L.B.; Talesh, S.A. To comply or not to comply-That isn't the question: How organizations construct the meaning of compliance. In Explaining Compliance: Business Responses to Regulation; Parker, C., Nielsen, V.L., Eds.; Edward Elgar Publishing: Cheltenham, UK, 2011; pp. 103-122.

4. Friedman, L.M. The law and society movement. Stanf. Law Rev. 1986, 38, 763-780. [CrossRef]

5. Mulligan, E.; Oats, L. Tax professionals at work in Silicon Valley. Account. Organ. Soc. 2015. [CrossRef]

6. Gracia, L.; Oats, L. Boundary work and tax regulation: A Bourdieusian view. Account. Organ. Soc. 2012, 37, 304-321. [CrossRef]

7. McBarnet, D.; Whelan, C. Creative Accounting and the Cross-Eyed Javelin Thrower; John Wiley \& Sons: Hoboken, NJ, USA, 1999. Available online: http://www.research.ed.ac.uk/portal/en/publications/creative-accountingand-the-crosseyed-javelin-thrower(eb9977ae-11d2-4f69-bfb7-c9165736b66e)/export.html (accessed on 31 October 2019). 
8. McBarnet, D. When Compliance Is Not the Solution but the Problem: From Changes in Law to Changes in Attitude. 2004. Available online: https://openresearch-repository.anu.edu.au/handle/1885/41635 (accessed on 31 October 2019).

9. Christians, A. Avoidance. Evasion, and Taxpayer Morality. Wash. Univ. J. Law Policy 2014, 44, 39-59.

10. OECD 2018 Glossary of Tax Terms. Available online: https://www.oecd.org/ctp/glossaryoftaxterms.htm (accessed on 31 October 2019).

11. Webley, P. Tax compliance by businesses. In New Perspectives on Economic Crime; Sjögren, H., Skogh, G., Eds.; Edward Elgar: Cheltenham, UK, 2004; pp. 95-126.

12. HM Revenue and Customs. 1999 IR35: Press Release Dated 9 March 1999. Retrieved 10 May 2016. Available online: http://webarchive.nationalarchives.gov.uk/20140109143644/http:/www.hmrc.gov.uk/ir35/ir35.htm (accessed on 31 October 2019).

13. Hobson, K. 'Say no to the ATO': The cultural politics of protest against the Australian Tax Office. Soc. Mov. Stud. 2004, 3, 51-71. [CrossRef]

14. Murphy, K. Procedural Justice and the Australian Taxation Office: A Study of Scheme Investors; Working paper no 56; Center for Tax System Integrity: Canberra, Australia, 2004. Available online: https://digitalcollections. anu.edu.au/bitstream/1885/42014/2/WP56.pdf (accessed on 31 October 2019).

15. Lay, D.; Thomas, N.; Oats, L.; Onu, D. Morality, Fairness, and the Law: An Analysis of Public Opinions on Tax Avoidance; University of Exeter: Exeter, UK, 2016; unpublished manuscript.

16. Braithwaite, V.; Braithwaite, J. Democratic Sentiment and Cyclical Markets in Vice. Br. J. Criminol. 2006, 46, 1110-1127. [CrossRef]

17. Braithwaite, V. Taxing Democracy: Understanding Tax Avoidance and Tax Evasion; Ashgate: Aldershot, UK, 2005.

18. Elffers, H.; Weigel, R.H.; Hessing, D.J. The consequences of different strategies for measuring tax evasion behaviour. J. Econ. Psychol. 1987, 8, 311-337. [CrossRef]

19. European Comission. Aggressive Tax Planning Indicators; Final Report-Working Paper No 71; Publications Office of the European Union: Luxembourg, 2017; Volume 7565.

20. Alm, J. Measuring, explaining, and controlling tax evasion: Lessons from theory, experiments, and field studies. Int. Tax Public Financ. 2012, 19, 54-77. [CrossRef]

21. Hanlon, M.; Heitzman, S. A review of tax research. J. Account. Econ. 2010, 50, 127-178. [CrossRef]

22. Hashimzade, N.; Myles, G.D.; Page, F.; Rablen, M.D. Social networks and occupational choice: The endogenous formation of attitudes and beliefs about tax compliance. J. Econ. Psychol. 2013. [CrossRef]

23. Kamleitner, B.; Korunka, C.; Kirchler, E. Tax compliance of small business owners: A review. Int. J. Entrep. Behav. Res. 2012, 18, 330-351. [CrossRef]

24. Kirchler, E. The Economic Psychology of Tax Behaviour; Cambridge University Press: Cambridge, UK, 2007.

25. Pickhardt, M.; Prinz, A. Behavioral dynamics of tax evasion-A survey. J. Econ. Psychol. 2013. [CrossRef]

26. Picciotto, S. Constructing Compliance: Game Playing, Tax Law, and the Regulatory State. Law Policy 2007, 29, 11-30. [CrossRef]

27. Datt, K.H. Paying a fair share of tax and aggressive tax planning-A tale of two myths. Ejournal Tax Res. 2014, 12, 410-432.

28. Kirchler, E.; Maciejovsky, B.; Schneider, F. Everyday representations of tax avoidance, tax evasion, and tax flight: Do legal differences matter? J. Econ. Psychol. 2003, 24, 535-553. [CrossRef]

29. Braithwaite, V.A. Taxing Democracy: Understanding Tax Avoidance and Evasion; Taylor \& Francis Ltd.: Milton Park, UK, 2003.

30. Allingham, M.G.; Sandmo, A. Income tax evasion: A theoretical analysis. J. Public Econ. 1972, 1, $323-338$. [CrossRef]

31. Andreoni, J.; Erard, B.; Feinstein, J. Tax Compliance. J. Econ. Lit. 1998, 36, 818-860. [CrossRef]

32. Hashimzade, N.; Myles, G.D.; Tran-Nam, B. Applications of Behavioural Economics to Tax Evasion. J. Econ. Surv. 2013, 27, 941-977. [CrossRef]

33. Feld, L.P.; Frey, B.S. Tax compliance as the result of a psychological tax contract: The role of incentives and responsive regulation. Law Policy 2007, 29, 102-120. [CrossRef]

34. Torgler, B. Speaking to Theorists and Searching for Facts: Tax Morale and Tax Compliance in Experiments. J. Econ. Surv. 2002, 16, 657-683. [CrossRef]

35. Wenzel, M. An analysis of norm processes in tax compliance. J. Econ. Psychol. 2004, 25, 213-228. [CrossRef] 
36. Myles, G.D.; Naylor, R.A. A model of tax evasion with group conformity and social customs. Eur. J. Political Econ. 1996, 12, 49-66. [CrossRef]

37. Bobek, D.D.; Roberts, R.W.; Sweeney, J.T. The Social Norms of Tax Compliance: Evidence from Australia, Singapore, and the United States. J. Bus. Ethics 2007, 74, 49-64. [CrossRef]

38. Cialdini, R.B.; Trost, M.R. Social Influence: Social Norms, Conformity and Compliance. In The Handbook of Social Psychology; Gilbert, D.T., Fiske, S.T., Lindzey, G., Eds.; McGraw-Hill: New York, NY, USA, 1998; pp. 151-192.

39. Wenzel, M. The Multiplicity of Taxpayer Identities and Their Implications for Tax Ethics. Law Policy 2007, 29, 31-50. [CrossRef]

40. Feld, L.P.; Frey, B.S. Trust breeds trust: How taxpayers are treated. Econ. Gov. 2002, 3, 87-99. [CrossRef]

41. Hartner, M.; Rechberger, S.; Kirchler, E.; Schabmann, A. Procedural fairness and tax compliance. Econ. Anal. Policy 2008, 38, 137-152. [CrossRef]

42. Kirchler, E.; Hoelzl, E.; Wahl, I. Enforced versus voluntary tax compliance: The "slippery slope" framework. J. Econ. Psychol. 2008, 29, 210-225. [CrossRef]

43. Braithwaite, V.A. Defiance in Taxation and Governance: Resisting and Dismissing Authority in a Democracy; Edward Elgar Publishing: Cheltenham, UK, 2009.

44. Kirchler, E. Differential representations of taxes: Analysis of free associations and judgments of five employment groups. J. Socio-Econ. 1998, 27, 117-131. [CrossRef]

45. Eriksen, K.; Fallan, L. Tax knowledge and attitudes towards taxation; A report on a quasi-experiment. J. Econ. Psychol. 1996, 17, 387-402. [CrossRef]

46. Kirchler, E.; Wahl, I. Tax Compliance Inventory: TAX-I Voluntary tax compliance, enforced tax compliance, tax avoidance, and tax evasion. J. Econ. Psychol. 2010, 31, 331-346. [CrossRef] [PubMed]

47. Soper, D.S. Significance of the Difference between Two Correlations Calculator [Software]. Retrieved 3 May 2016. Available online: http://www.danielsoper.com/statcalc (accessed on 31 October 2019).

48. Onu, D.; Oats, L. Tax Talk: An Exploration of Online Discussions Among Taxpayers. J. Bus. Ethics 2016, 1-14. [CrossRef] [PubMed]

49. Onu, D.; Oats LKirchler, E. The Dynamics of Internalised and Extrinsic Motivation in the Ethical Decision-Making of Small Business Owners. Appl. Psychol. 2018, 68, 177-201. [CrossRef]

50. Collins, D. Pretesting survey instruments: An overview of cognitive methods. Qual. Life Res. 2003, 12, 229-238. [CrossRef]

51. Barham, E.; Fox, K. 2011 Compliance Perceptions Survey-Individuals 2008-10. HM Revenue and Customs Research Report 156. Available online: http://www.hmrc.gov.uk/research/cps-ind-report156.pdf (accessed on 31 October 2019).

52. Hofmann, E.; Voracek, M.; Bock, C.; Kirchler, E. Tax compliance across sociodemographic categories: Meta-analyses of survey studies in 111 countries. J. Econ. Psychol. 2017, 62, 63-71. [CrossRef]

53. Hayes, A.F. Introduction to Mediation, Moderation, and Conditional Process Analysis: A Regression-Based Approach; Guilford Press: New York, NY, USA, 2013.

54. Frey, B.S.; Torgler, B. Tax morale and conditional cooperation. J. Comp. Econ. 2007, 35, 136-159. [CrossRef]

55. Muehlbacher, S.; Kirchler, E. Rechtspsychologische Betrachtung der Bestrafung von Steuerhinterziehung; Faculty of Psychology, University of Vienna: Vienna, Australia, 2007; unpublished manuscript.

56. Gneezy, U.; Rustichini, A. A fine is a price. J. Leg. Stud. 2000, 29, 1. [CrossRef]

57. Wenzel, M. Motivation or rationalisation? Causal relations between ethics, norms and tax compliance. J. Econ. Psychol. 2005, 26, 491-508. [CrossRef]

58. Ajzen, I. The theory of planned behavior. Organ. Behav. Hum. Decis. Process. 1991, 50, 179-211. [CrossRef]

59. Miller, D.T. The norm of self-interest. Am. Psychol. 1999, 54, 1053-1060. [CrossRef]

60. Ashby, J.S.; Webley, P. 'But everyone else is doing it': A closer look at the occupational taxpaying culture of one business sector. J. Community Appl. Soc. Psychol. 2008, 18, 194-210. [CrossRef]

61. Elffers, H.; Robben, H.S.J.; Hessing, D.J. On measuring tax evasion. J. Econ. Psychol. 1992, 13, $545-567$. [CrossRef] 
62. Bobek, D.D.; Hatfield, R.C. An Investigation of the Theory of Planned Behavior and the Role of Moral Obligation in Tax Compliance. Behav. Res. Account. 2003, 15, 13-38. [CrossRef]

63. Measuring Tax Gaps 2015-Tax Gap Estimates for 2013-14. 2015 HM Revenue and Customs. Available online: https://assets.publishing.service.gov.uk/government/uploads/system/uploads/attachment_data/file/ 469970/HMRC-Measuring-tax-gaps-2015.pdf (accessed on 31 October 2019).

(C) 2019 by the authors. Licensee MDPI, Basel, Switzerland. This article is an open access article distributed under the terms and conditions of the Creative Commons Attribution (CC BY) license (http://creativecommons.org/licenses/by/4.0/). 